\title{
デンプン源および蛋白質源の違いが去勢牛による窒素の 消化管部位別消化之窒素出納に及ぼす影響
}

\author{
花田正明・小匮剛人 $*$ 谷口幸三* \\ 北海道立根釧農業試験場，北海道中標津汀 086-11 \\ *広島大学生物生産学部, 東広島市 724
}

(1992.6. 17 受付)

\begin{abstract}
要 約 反㫚胃，十一指腸前位部扰よび问腸末端にカニューレを装着したホルスタイン種去勢牛 4 頭 (平均体重： $227 \mathrm{~kg}$ ) を供試し、デンプン源（大麦・トウモロコシ）および蛋白質源（大豆粕・コーン グルテンミール）の組合せの違いが窒菜の消化管部位別消化ならびに窒素出納に及ぼす影響を $4 \times 4$ の ラテン方格法により検討した。供試した各飼料は，細切乾草と灌厚飼料との混合割合ををれぞれ $50 \%$ とし，粗蛋白質含量を等しくした $(11 \%)$ ）飼料給与量は，日增体量 $0.7 \mathrm{~kg} に$ に必要な可消化エネルギ 一を满たす量とした，大麦給与区に比べトゥモロコシ給与区，大豆粕給与区に比べコーングルテンミー ル給与区で，十一指腸への全窒素之飼料由来の空素流入量加增加した $(\mathrm{P}<0.01)$. 十一指腸へ流入し た菌体窑素量はデンプン源の影響を受け，大麦給与によって增加したが（P<0.05），蛋白質源の影響 はなかった，十二指腸に流入した全窒菜の小腸内見かけの消化率は，処理間で差がなく，十二指腸への

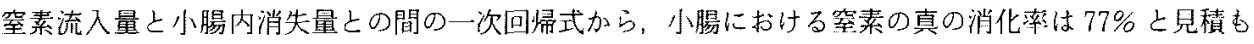
られた，十二指腸への必須了ミ，酸流入量之小腸内消失量はデンプン源に影響されなかったが，大豆粕 給与区に比べコーングルテンミール給与区で増加した。しかしリジンの小腸内消失星は処埋間に差がな く，また窒素蓄積量にも処理間に差は認められなかった。トゥモロコシとコーングルテンミールの組合 せ络反独罗内への窒素再循環量を増やすことが示唆された。
\end{abstract}

日畜会報，64(3)：275-287, 1993

反驾置で分解される飼料蛋白質は微生物体蛋白質に变

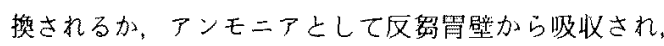
䀒臟て尿素となって，その多くは尿中に排泄される，飼 料蛋白質の反望胃内分解度は飼料の種類に上って異なり，

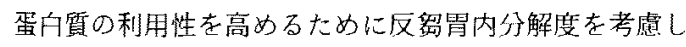

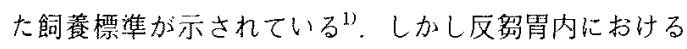
徽生物体蛋白質の合成は窒素源や微生物への土ネルギー

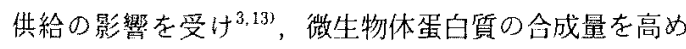
るためには，飼料蛋白質の分解度や微生物へのエネルギ 一供給について本考甞しなけ机ばならい。デンプンは， 微生物が利用しやすいエネルギ一供給源であるが，㓽類 の㮔類によってデンプンの反捌胃内における分解度は異 なることが知られている゙7. 従って蛋白質源とデンプン 源の遙いによって微生物体蛋白質の合成量が変動し，ひ いては十一指腸へ流入する蛋白質量や組成に影㗽するこ とが予想される。また反努家畜のアミ/酸要求量は確定
していないが，デンプン源や蛋白質源の違によって小 晹で消化されるアミ/酸量が珙なる上，個体レベルでの 窒素利用性に影響するかもしれない。

飼料蛋白質源の避いに上る小腸への蛋白質流入量に関 する研究は多いものの，飼料蛋白質由来の小腸における 等素 (UDN) やアミノ酸の利用性に関する硚究は少な い32．UDNの小腸内消化率は飼料源によって暴なると

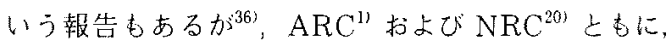

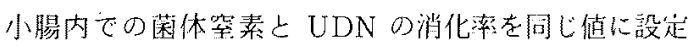
している.

著者らは，すでにデンプン源と蛋白質源の級合せによ る違いがデンプンおよび瀻維澌の消化管部位別消化に及

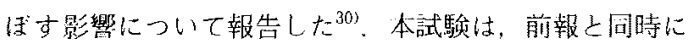
奉施したものであり，反留罗内分解度が異なるデンプン 源之蛋白質源の給与が，去勢牛における窣素の消化管部 位別消化ならびに個休レベルでの窒素利用性に及ぼす影 
獾にっいて㭥討した。

\section{材料および方法}

供試動物之給与飼料：反秋置，十二指腸上部および 回腸末端にシンプルカニューレを装着したホルスタイン 種去勢牛 4 頭（試験開始時の平均体重；227 kg）を供給 した．飼料はデンプン源および蛋白質源の異なる4種類 の飼料老供試した。試験は，1）压ペントウモロコシナ 大豆粕（以下，CS），2）压ベントゥモロコシ十コーン グルテンミール (CC)，3）压ペン大表十大豆粕（BS）, 压ペン大麦+コーングルテンミール（BC）を給与する 4 処理区在設け，4风4のラテン分格法に上り尖施した。 給与飼料の配合割合上化学成分を走 1 に示した．各飼料 と屯凯物中心粗蛋白質含量を $11 \%$ ，濃厚飼料上細切し たイタリアンライグラス乾草の混合割合をそれぞれ 50 。ずつ(乾物重量比) とした，飼料の給与量は，日增 体量 $0.7 \mathrm{~kg}$ に必要な可消化エネルギーを満たす量とし た

した，各消化管部位への内谷物の流入量および排筫量の
測定のため，指示物質として酸化第一っロムを州い，試

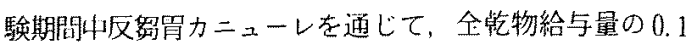
$\%$ 相当量を 1 日 2 囘に分け, 飼料給与時に等量ずつ投 与した，水は目由摂取させた。

試駼期間および試料採取：試験期問は 1 期 22 日閒 とし，最初の 14 日問を予備期，その後の8 日閒を試料 採取期問之した。試験開始前日之各試験期の最終日，每 15:00に体重莸計測した。試料採取期間の1 日日から 4 日日までは給与飼料，残食，資拉上び尿の採取を行な

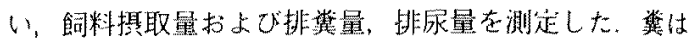
1 日 3 囘，1:00，9:00，17:00に排泄翼の一部を採取 した，採取した飼料，残食および穓はそれぞれ個体重に 混合して, $55^{\circ} \mathrm{C}$ の通風乾燥器内で 48 時間乾燥した後, 粉砕して分析に供した，尿は $50 \%$ 琉酸を添加した㝘器 に全量を採取し，計量後その一部を分析時まで涷結保存 （以下全て $20^{\circ} \mathrm{C}$ ）した，試料採取期第 4 日目の飼料給 与前および給与 2 時間後に, 血中心遊離アミ/酸濃度を

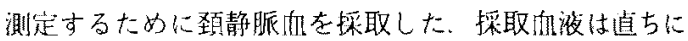
$4^{\circ} \mathrm{C}$ 下で血漿を分離し，分析時まで凍結保存した。第 5

Table 1. Ingredients and chemical composition of diets on a dry matter basis

\begin{tabular}{|c|c|c|c|c|}
\hline & \multicolumn{4}{|c|}{ Diets } \\
\hline & \multicolumn{2}{|c|}{ Corn } & \multicolumn{2}{|c|}{ Barley } \\
\hline & $\begin{array}{l}\text { Soybean } \\
\text { meal }\end{array}$ & $\begin{array}{l}\text { Corn gluten } \\
\text { meal }\end{array}$ & $\begin{array}{c}\text { Soybean } \\
\text { meal }\end{array}$ & $\begin{array}{c}\text { Corn gluten } \\
\text { meal }\end{array}$ \\
\hline \multicolumn{5}{|l|}{ Ingredients, $\%$} \\
\hline Italian ryegrass hay & 50,0 & 50.0 & 50.0 & 50.0 \\
\hline Steam-flaked corn & 38.5 & 41.3 & - & $\ldots-\cdots$ \\
\hline Steam-rolled barley & - & - & 40.5 & 42.7 \\
\hline Soybean meal & 8.5 & - & 6.5 & - \\
\hline Corn gluten meal & - & 5.7 & - & 4.3 \\
\hline Calcium phosphate monobasic & 0.6 & 0.6 & 0.6 & 0.6 \\
\hline Calcium carbonate & 0.8 & 0.8 & 0.8 & 0.8 \\
\hline Sodium chloride & 0.5 & 0.5 & 0.5 & 0.5 \\
\hline Mineral/vitamin $\operatorname{mix}^{11}$ & 1.0 & 1.0 & 1.0 & 1.0 \\
\hline Chromic oxide ${ }^{21}$ & 0.1 & 0.1 & 0.1 & 0.1 \\
\hline \multicolumn{5}{|l|}{ Chemical component, 8} \\
\hline Crude ash & 5.3 & 4.9 & 5.4 & 5.2 \\
\hline Crude protein & 11.9 & 11.8 & 11.4 & 11.5 \\
\hline Starch & 24.8 & 27.6 & 29.6 & 31.1 \\
\hline Neutral detergent fiber & 43.9 & 43.6 & 42.6 & 42.7 \\
\hline Gross energy, MJ/kg & 18.4 & 18.5 & 18.1 & 18.2 \\
\hline
\end{tabular}

1) Contains $\mathrm{MgSO}_{4}, 200 \mathrm{~g} ; \mathrm{FeSO}_{4}, 3.2 \mathrm{~g} ; \mathrm{MnCO}_{3}, 2.3 \mathrm{~g} ; \mathrm{ZnCO}_{3}, 3.5 \mathrm{~g} ; \mathrm{CuSO}_{4}, 1.4 \mathrm{~g} ; \mathrm{Ca}\left(\mathrm{IO}_{3}\right)_{2}, 10 \mathrm{mg}$; $\mathrm{CoSO}_{4}, 20 \mathrm{mg}$; Vit. A, $400000 \mathrm{IU}$; Vit. D, $40000 \mathrm{IU}$; Vit. E, $2000 \mathrm{mg}$ per kg.

2) Administered into the rumen through the cannula. 


\section{去勢牛の消化管部位別窑素消化}

日日・6日日に十一指晹之问晹内谷物の採取を 4 時䦌間 隔で行なったが，5日日は9：00を，6日日は11：00を 起点とした。な，反絢胃内谷物の襍相の通過速度は十 一指腸内谷物を用いて調べ，予め第 5 日目の $9: 00$ に 40 \% PEG（平均分子量： 3,000 ）溶液 $100 \mathrm{ml}$ を反蜀胃 内へ投与した，各採取内容物は個体每に混合し，伶蔵保 存した。採取期品終了备後, 内容物の一部をアンモニア 態等素上 PEG 濃度湘定用として凍絬保存し, 残りの サンプルは，谏結乾燥後，粉砕してそれぞれ分析に供し た. 試料蜉取期間の 7 日目に，9：00の䀦料給与加ら0,

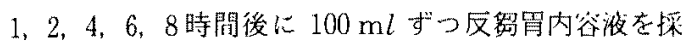
取した，反蜀留内容液採取後，50\%硫酸 $1 \mathrm{ml}$ を添加 し，分析時まで涷結保存した，最終曰の朝の飼料給与か ら 2 時間後に，各個体から反贸胃内容液を $800 \mathrm{ml}$ ずつ 採取した。採取した内容液は, 直ちにSMTTH and $\mathrm{MCALLAN}^{26)}$ の方法に従って反唿胃内微生物を分離し，

凍結乾燥した。

分析方法㧍上び統計処理：給与飼料と残食, 消化管 内容物ならびに排泄粪中の乾物・有機物・等素・中性デ タージェント紻維・デンプン・クロム・エネルギー含量 および尿中窒素含量と消化管内谷物中アンモ二ア態案素

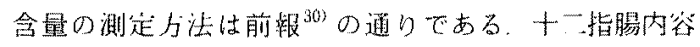

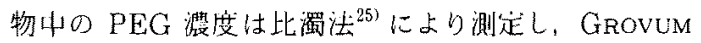
and WiLLIAMS ${ }^{9)}$ の法に従って液相の通過速度を算出し た。十一指腸ならびに回腸内谷物のアミノ酸含量の測定 は, 試料 $50 \mathrm{mg}$ に $6 \mathrm{~N}$ 塩酸を $5 \mathrm{ml}$ 添加し, $110^{\circ} \mathrm{C}$, 24 時間加水分解後，また血墏山心遊離了ミノ酸は，又 ルホサりチル酸で除蛋白した後33，高速液体クロマトグ ラフィー装置（日本分光 K. K) 存用いて OPA 法 ${ }^{7.87}$ により測定した。

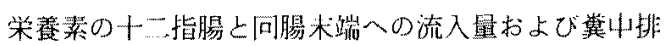
洺量は消化管内容物中の栄養素上ク口ム含量加ら算仙し た。反蜀罥内谷䍇から分離した細菌のプリン含量は ZINN and OWENS ${ }^{39}$ のち法により測定し, 菌体のプリ ンと萆素との比を求め，十二指腸へのプリン流入量加ら 十一指腸への莉体空素流入量を求好た，一指腸八流入 したUDN 量は，十一指晹へ流入した全窑素量からア ンモニア態空素扰よび菌休窣菜量を差し引いて求めた。 また反曶胃内で分解された飼料蛋白質由来の窣素 (RDN) 量は，突素摂取量加 UDN 差し引いて求めた。

得られた結果は $4 \times 4$ のラテン方格法により，個休，

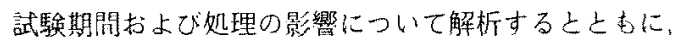

Table 2. Intake and disappearance of organic matter, starch, neutral detergent fiber and energy from the rumen of steers fed diets containing either corn or barley and soybean meal or corn gluten meal.

\begin{tabular}{|c|c|c|c|c|c|c|c|c|}
\hline \multirow[b]{3}{*}{ Item } & \multicolumn{4}{|c|}{ Treatments } & & & & \\
\hline & \multicolumn{2}{|c|}{ Corn } & \multicolumn{2}{|c|}{ Barley } & \multicolumn{4}{|c|}{ Significance of difference } \\
\hline & $\begin{array}{c}\text { Soybean } \\
\text { meal }\end{array}$ & $\begin{array}{c}\text { Corn gluten } \\
\text { meal }\end{array}$ & $\begin{array}{l}\text { Soybean } \\
\text { meal }\end{array}$ & $\begin{array}{l}\text { Corn gluten } \\
\text { meal }\end{array}$ & SEM $^{11}$ & $\begin{array}{l}\text { Starch } \\
\text { effect }\end{array}$ & Protein & $\begin{array}{l}\text { Starch } x \\
\text { protein }\end{array}$ \\
\hline \multicolumn{9}{|l|}{ Intake } \\
\hline Organic matter, $\mathrm{kg} / \mathrm{d}$ & 4.62 & 4.56 & 4.61 & 4.79 & 0.10 & $\mathrm{NS}^{21}$ & NS & NS \\
\hline Starch, $\mathrm{kg} / \mathrm{d}$ & $1.23^{\mathrm{a}}$ & $1.37^{b}$ & $1.49^{b c}$ & $1.61^{c}$ & 0.03 & $* *$ & $* *$ & NS \\
\hline $\begin{array}{l}\text { Neutral detergent fiber, } \\
\mathrm{kg} / \mathrm{d}\end{array}$ & 2.11 & 2.04 & 2.01 & 2.11 & 0.06 & NS & NS & NS \\
\hline Gross energy, $\mathrm{MJ} / \mathrm{d}$ & 89.7 & 89.4 & 87.8 & 91.8 & 2.0 & NS & NS & NS \\
\hline \multicolumn{9}{|c|}{ Disappearance from the rumen } \\
\hline Organic matter, kg/d & $2.22^{\mathrm{ab}}$ & $1.76^{\mathrm{a}}$ & $2.44^{\mathrm{b}}$ & $2.61^{b}$ & 0.13 & $*$ & NS & * \\
\hline Starch, kg/d & $0.81^{\mathrm{a}}$ & $0.79^{2}$ & $1.32^{\mathrm{t}}$ & $1.44^{\mathrm{b}}$ & 0.06 & $* *$ & NS & NS \\
\hline $\begin{array}{l}\text { Neutral detergent fiber, } \\
\mathrm{kg} / \mathrm{d}\end{array}$ & 1.17 & 1.05 & 0.99 & 1.11 & 0.03 & NS & NS & NS \\
\hline Energy, $\mathrm{MJ} / \mathrm{d}$ & $38.8^{\mathrm{ab}}$ & $29.4^{\mathrm{a}}$ & $42.0^{\circ}$ & $44.5^{b}$ & 2.1 & $* *$ & NS & $*$ \\
\hline
\end{tabular}

1) Standard error of means.

2) $\mathrm{NS}: \mathrm{P}>0.05$.

3) Apparent digestibility.

$a, b, c$ Mean values in the same row with different superscripts differ significantly $(P<0.05)$.

$* P<0.05, * P<0.01$. 


\section{化田・小灀・谷口}

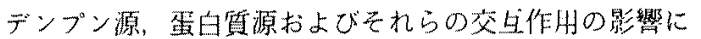
ついて2元配琶法により解析した ${ }^{28)}$.

\section{結果}

平均日增体量は CS, CC, BS および BC 区でそれだ れ $0.8,0.8,0.8,0.7 \mathrm{~kg} /$ 日であり，処理間に差はな 加大 $(\mathrm{P}>0.05)$.

有機物および NDF 掑取量は，表2 に示したように 処理闍に差がなかったが、デンプン摄取量は，トウモロ コシ給与区，(以下 CBD 区）に比べ大麦給与区（BBD
メ）で，また大至粕給与区（SBM 区）に比べコーング ルテンミール給与区（CGM 区）で多かった（ $\mathrm{P}<0.01 ）$. 反鴐罢内に打ける有機物・デンブン・エネルギーの消失 量は，いずれも CBD爻に比べ BBD 边亭い值を示 Lた $(\mathrm{P}<0.01)$.

等素椇取量は処理間に有意差はなく，各区と6 $90 \mathrm{~g} /$

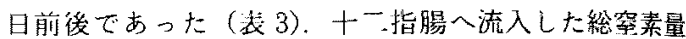
はデンプン源および蛋白質源双方の影響を受け，BBD 区より委 CBD 区で，また SBM 区よりも CGM 区で

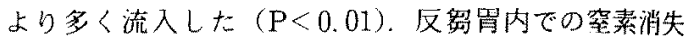

Table 3. Nitrogen digestion and balance of steers fed diets containing either corn or barley and soybean meal or corn gluten meal.

\begin{tabular}{|c|c|c|c|c|c|c|c|c|}
\hline \multirow[b]{3}{*}{ Item } & \multicolumn{4}{|c|}{ Treatments } & \multirow[b]{3}{*}{$\mathrm{SEM}^{11}$} & & & \\
\hline & \multicolumn{2}{|c|}{ Corn } & \multicolumn{2}{|c|}{ Barley } & & \multicolumn{3}{|c|}{ Significance of difference } \\
\hline & $\begin{array}{l}\text { Soybean } \\
\text { meal }\end{array}$ & $\begin{array}{l}\text { Corn gluten } \\
\text { meal }\end{array}$ & $\begin{array}{l}\text { Soybean } \\
\text { meal }\end{array}$ & $\begin{array}{l}\text { Corn gluten } \\
\text { meal }\end{array}$ & & $\begin{array}{l}\text { Starch } \\
\text { effect }\end{array}$ & $\begin{array}{l}\text { Protein } \\
\text { effect }\end{array}$ & $\begin{array}{l}\text { Starch } x \\
\text { protein }\end{array}$ \\
\hline Intake, $\mathrm{g} / \mathrm{d}$ & 93.9 & 92.0 & 89.6 & 94.4 & 2.6 & $\mathrm{NS}^{21}$ & NS & NS \\
\hline $\begin{array}{l}\text { Passage to duodenum, } \\
\mathrm{g} / \mathrm{d}\end{array}$ & $91.4^{\mathrm{a}}$ & $120.8^{b}$ & $89.3^{a}$ & $100.7^{a}$ & 2.8 & $* *$ & $* *$ & NS \\
\hline $\begin{array}{l}\text { Passage to terminal } \\
\text { ileum, } \mathrm{g} / \mathrm{d}\end{array}$ & 37.5 & 40.2 & 34.0 & 37.0 & 2.0 & NS & NS & NS \\
\hline Excretion to feces, g/d & $35.6^{a}$ & $36.1^{a}$ & $28.7^{\mathrm{ab}}$ & $31.3^{\mathrm{ab}}$ & 1.8 & $* *$ & NS & NS \\
\hline $\begin{array}{l}\text { Disappearance, } \mathrm{g} / \mathrm{d} \\
\text { From rumen }\end{array}$ & $2.4^{a}$ & $-28.8^{b}$ & $0.4^{\mathrm{a}}$ & $-6.2^{\mathrm{a}}$ & 4.1 & * & $* *$ & $*$ \\
\hline From small intestine & $53.9^{a}$ & $80.6^{b}$ & $55.3^{a}$ & $63.7^{\mathrm{ab}}$ & 3.9 & NS & $* *$ & NS \\
\hline From large intestine & 1.8 & 4.1 & 5.3 & 5.7 & 1.2 & NS & NS & NS \\
\hline \multicolumn{9}{|l|}{$\begin{array}{l}\text { Apparent digestibility } \\
\text { \% of intake }\end{array}$} \\
\hline Rumen & $2.5^{b}$ & $-31.3^{a}$ & $0.4^{b}$ & $-6.2^{b}$ & 4.3 & * & $* *$ & $*$ \\
\hline Small intestine & $57.4^{\mathrm{a}}$ & $87.6^{b}$ & $61.7^{\mathrm{a}}$ & $67.1^{\text {ab }}$ & 4.8 & NS & * & * \\
\hline $\begin{array}{l}\text { Large intestine } \\
\text { of flow }\end{array}$ & 1.9 & 4.4 & 6.0 & 6.0 & 1.2 & NS & NS & NS \\
\hline Small intestine & 59.0 & 66.7 & 61.8 & 63.0 & 2.7 & NS & NS & NS \\
\hline Large intestine & 4.2 & 10.0 & 15.3 & 15.2 & 2.8 & $*$ & NS & NS \\
\hline Total tract, $\%$ & 62.2 & 60.7 & 68.0 & 66.8 & 1.4 & * & NS & NS \\
\hline \multicolumn{9}{|l|}{ Nitrogen balance } \\
\hline Excretion to urine, $\mathrm{g} / \mathrm{d}$ & 27.9 & 28.8 & 32.8 & 28.6 & 1.4 & NS & NS & NS \\
\hline Retention, $\mathrm{g} / \mathrm{d}$ & 30.4 & 27.1 & 28.2 & 34.6 & 3.2 & NS & NS & NS \\
\hline \multicolumn{9}{|l|}{ Proportion to intake, 8} \\
\hline Excretion to urine & 29.7 & 31.3 & 36.6 & 30.3 & 2.0 & NS & NS & NS \\
\hline Retention & 32.5 & 29.4 & 31.4 & 36.6 & 2.6 & NS & NS & NS \\
\hline \multicolumn{9}{|c|}{$\begin{array}{l}\text { Proportion to absorbed nitrogen } \\
\text { from small intestine, of }\end{array}$} \\
\hline Retention & 56.4 & 33.6 & 51.0 & 54.3 & 6.5 & NS & NS & NS \\
\hline
\end{tabular}




\section{去勢牛の消化管部位別窒素消化}

量は CC および BC 区では負の值を示したが，デンブ ン源之蛋白質源閣の交互作用が有意であった。回腸末端 に流入した窒素量は，処理間に有意差はなかった。この ため小腸内窒素消失量は SBM 区よりも CGM 区で多 $<(P<0.01)$, 摂取量に対する小腸内窒菜消化率も, CGM 区が高い值を示した $(\mathrm{P}<0.05)$. しかし十二指 腸へ流入した䓨素量に対する小腸内窒素消失量の割合で みると，処理間に有意差はなかった，瞥への窒素排泄量 は，BBD区に比べ CBD 区で多く（P<0.01），大腸 への答菜流入䝿に対する消失量の割合は，CBD区に比 ヘ BBD 区が高かった $(\mathrm{P}<0.05)$. 結果として全消化 管消化率は，CBD 区に比べ BBD 区が高い值を示した $(\mathrm{P}<0.05)$.

尿中室素排泄量は処理間に差はなく $(\mathrm{P}>0.05)$ ，空
素蕃積量も BC 区で高く，CC区で低い傾向を示した すのの，処理閶に有意差はなかった（表了），小腸内消 失窒素量に対する窒菜蓄積量の割合は有意でないが, CC 区では他の 3 区に比べてかなり減少した。

十二指腸に流入した非アンモ二ア態窒素および UDN 量はBBD 区に比べ CBD 区で，また SBM 区に比べ CGM 区で多かった（表 4，P<0.01），十二指腸への菌 体窒素の流入量は CBD 区ょりあ BBD 区で多かった $(\mathrm{P}<0.05)$ か，蛋白質源の影響はなかった，CBD区に 比べBBD区では，十一指腸に流入しだ全窑素に占め る菌体窒素の割合が高く $(\mathrm{P}<0.01)$ ，逆に $\mathrm{CBD}$ 区で はUDN の割合が高かった $(P<0.01)$.

反罚胃内に求ける飼料蛋白質の分解度之内溶液中のア ンモニア態窒素濃度は CBD 区上りすBBD区に挹い

Table 4. Liquid passage rate, ammonia concentration, nitrogen degradability in the rumen and nitrogen compounds flow to duodenum of steers fed diets containing either corn or barley and soybean meal or corn gluten meal.

\begin{tabular}{|c|c|c|c|c|c|c|c|c|}
\hline \multirow[b]{3}{*}{ Item } & \multicolumn{4}{|c|}{ Treatments } & & & & \\
\hline & \multicolumn{2}{|c|}{ Corn } & \multicolumn{2}{|c|}{ Barley } & \multicolumn{4}{|c|}{ Significance of difference } \\
\hline & $\begin{array}{l}\text { Soybean } \\
\text { meal }\end{array}$ & $\begin{array}{l}\text { Corn gluten } \\
\text { meal }\end{array}$ & $\begin{array}{l}\text { Soybean } \\
\text { meal }\end{array}$ & $\begin{array}{c}\text { Corngluten } \\
\text { meal }\end{array}$ & $\mathrm{SEM}^{1 /}$ & $\begin{array}{l}\text { Starch } \\
\text { effect }\end{array}$ & $\begin{array}{l}\text { Protein } \\
\text { effect }\end{array}$ & $\begin{array}{l}\text { Starch } x \\
\text { protein }\end{array}$ \\
\hline Liquid passage rate, $\% / \mathrm{h}$ & $8.94^{\mathrm{a}}$ & $8.13^{\mathrm{a}}$ & $11.29^{\circ}$ & $10.54^{b}$ & 0.78 & $*$ & $\mathrm{NS}^{21}$ & NS \\
\hline $\begin{array}{l}\text { Ammonia concentration, } \\
\mathrm{mg} / \mathrm{d} l\end{array}$ & $6.94^{\mathrm{ab}}$ & $4.28^{a}$ & $8.05^{b}$ & $6.93^{\mathrm{ab}}$ & 0.61 & $*$ & $*$ & NS \\
\hline Degradability of nitrogen & $\mathrm{en}, 35.8^{\mathrm{a}}$ & $15.4^{b}$ & $52.3^{c}$ & $45.5^{\mathrm{ac}}$ & 3.0 & $* *$ & $* *$ & NS \\
\hline Flow to duodenum & & & & & & $* *$ & $* *$ & NS \\
\hline Non-ammonia $\mathrm{N}^{3\}} \mathrm{g} / \mathrm{d}$ & $90.2^{z}$ & $119.7^{b}$ & $87.7^{\mathrm{a}}$ & $99.5^{a}$ & 2.7 & $* *$ & $* *$ & NS \\
\hline Microbial $\mathrm{N}^{4}, \mathrm{~g} / \mathrm{d}$ & $30.2^{\mathrm{a}}$ & $42.0^{\mathrm{ab}}$ & $45.1^{b}$ & $48.6^{b}$ & 3.2 & $*$ & NS & NS \\
\hline $\begin{array}{l}\text { Undegraded } N \text { in the } \\
\text { rumen } 5 \text {, } g / d\end{array}$ & $60.1^{a b}$ & $77.7^{\mathrm{a}}$ & $42.6^{6}$ & $51.0^{b}$ & 2.7 & $* *$ & $* *$ & NS \\
\hline \multicolumn{9}{|l|}{ Composition of duodenal } \\
\hline Ammonia N, $\%$ & $1.3^{\mathrm{ab}}$ & $0.9^{a}$ & $1.8^{b}$ & $1.1^{\mathrm{a}}$ & 0.1 & $*$ & ** & NS \\
\hline Non-ammonia $\mathrm{N}^{31}, 8$ & $98.7^{\mathrm{ab}}$ & $99.1^{\mathrm{b}}$ & $98.2^{\mathrm{a}}$ & $98.9^{b}$ & 0.1 & $*$ & $* *$ & NS \\
\hline Microbial $\mathrm{N}^{4}, \%$ & $32.5^{\mathrm{a}}$ & $34.4^{\mathrm{a}}$ & $50.2^{b}$ & $47.0^{\mathrm{b}}$ & 2.2 & $* *$ & NS & NS \\
\hline $\begin{array}{l}\text { Undegraded } N \text { in the } \\
\text { rumen }{ }^{51}, \% 6\end{array}$ & $66.2^{a}$ & $64.7^{\mathrm{a}}$ & $48.0^{\circ}$ & $51.6^{\circ}$ & 2.3 & $* *$ & NS & NS \\
\hline $\begin{array}{l}\text { Microbial nitrogen synthe } \\
\mathrm{g}^{/ \mathrm{kg}} \mathrm{DOMR}^{6}\end{array}$ & $\begin{array}{l}\text { hesis } \\
13.8\end{array}$ & 24.2 & 18.6 & 18.7 & 2.2 & NS & NS & NS \\
\hline $\begin{array}{l}\text { 1) Standard error of mea } \\
\text { 2) NS: } P>0.05 \\
\text { 3) Total nitrogen-ammo } \\
\text { 4) Determined with the } n \\
\text { 5) Undegraded nitrogen } i \\
\text { 6) Organic matter appar } \\
\text { a, b.c. Mean values in the } \\
\text { * } P<0.05 \text {, ** } P<0.01 \text {. }\end{array}$ & $\begin{array}{l}\text { eans. } \\
\text { onia nitro } \\
\text { method o } \\
\text { in the ru } \\
\text { rently dig } \\
\text { he same r }\end{array}$ & $\begin{array}{l}\text { ogen. } \\
\text { of } \mathrm{Z} \text { INN and } 0 \\
\text { imen = non-an } \\
\text { gested in the } \\
\text { ow with diffe }\end{array}$ & $\begin{array}{l}\text { WENS ( } 198 \\
\text { mmonia N } \\
\text { rumen. } \\
\text { erent super }\end{array}$ & 86) & nitrogen & n. & & \\
\hline
\end{tabular}


Table 5. Profiles of amino acids flowing to duodenum of steers fed diets containing either corn or barley and soybean meal or corn gluten meal.

\begin{tabular}{|c|c|c|c|c|c|c|c|c|}
\hline \multirow[b]{3}{*}{ Item } & \multicolumn{4}{|c|}{ Treatments } & & & & \\
\hline & \multicolumn{2}{|c|}{ Corn } & \multicolumn{2}{|c|}{ Barley } & \multicolumn{4}{|c|}{ Significance of difference } \\
\hline & $\begin{array}{l}\text { Soybean } \\
\text { meal }\end{array}$ & $\begin{array}{l}\text { Corn gluten } \\
\text { meal }\end{array}$ & $\begin{array}{l}\text { Soybean } \\
\text { meal }\end{array}$ & $\begin{array}{c}\text { Corngluten } \\
\text { meal }\end{array}$ & SEM $^{11}$ & $\begin{array}{l}\text { Starch } \\
\text { effect }\end{array}$ & $\begin{array}{l}\text { Protein } \\
\text { effect }\end{array}$ & $\begin{array}{l}\text { Starch } x \\
\text { protein }\end{array}$ \\
\hline \multicolumn{9}{|l|}{ Flow, $g / d$} \\
\hline Threonine & $25.1^{\mathrm{ab}}$ & $29.6^{a}$ & $22.6^{b}$ & $25.8^{\mathrm{ab}}$ & 1.4 & $\mathrm{NS}^{21}$ & $*$ & NS \\
\hline Valine & $29.4^{\mathrm{ab}}$ & $36.2^{\mathrm{a}}$ & $27.0^{\mathrm{b}}$ & $29.3^{\mathrm{ab}}$ & 1.8 & $*$ & $*$ & NS \\
\hline Methionine & 5.1 & 6.3 & 4.5 & 4.6 & 0.7 & NS & NS & NS \\
\hline Isoleucine & 23.5 & 28.8 & 22.1 & 26.4 & 1.5 & NS & * & NS \\
\hline Leucine & $44.4^{\mathrm{ac}}$ & $71.5^{\mathrm{b}}$ & $34.2^{\mathrm{a}}$ & $48.4^{\mathrm{c}}$ & 2.6 & $* *$ & $* *$ & $*$ \\
\hline Phenylalanine & $23.0^{\mathrm{a}}$ & $32.5^{\mathrm{b}}$ & $21.5^{\mathrm{a}}$ & $26.9^{\mathrm{ab}}$ & 1.3 & $*$ & $* *$ & NS \\
\hline Histidine & 18.9 & 23.7 & 16.9 & 20.0 & 1.6 & NS & NS & NS \\
\hline Lysine & 33.8 & 34.2 & 39.0 & 37.9 & 3.7 & NS & NS & NS \\
\hline Arginine & 14.5 & 17.2 & 13.6 & 16.0 & 1.0 & NS & * & NS \\
\hline Essential amino acids & $217.7^{\mathrm{ab}}$ & $279.9^{\mathrm{a}}$ & $201.3^{\mathrm{b}}$ & $235.3^{\mathrm{ab}}$ & 13.4 & NS & $*$ & NS \\
\hline Total amino acids & $476.7^{\mathrm{a}}$ & $628.9^{\mathrm{b}}$ & $424.8^{\mathrm{a}}$ & $514.4^{\mathrm{ab}}$ & 23.6 & * & $* *$ & NS \\
\hline \multicolumn{9}{|c|}{ Composition, mol\% of total amino acids } \\
\hline Threonine & $5.47^{\mathrm{a}}$ & $4.89^{b}$ & $5.55^{2}$ & $5.23^{\mathrm{ab}}$ & 0.11 & NS & $* *$ & NS \\
\hline Valine & 6.50 & 6.08 & 6.76 & 6.02 & 0.17 & NS & * & NS \\
\hline Methionine & 0.89 & 0.83 & 0.87 & 0.73 & 0.11 & NS & NS & NS \\
\hline Isoleucine & $4.66^{\mathrm{ab}}$ & $4.32^{\mathrm{a}}$ & $4.93^{\mathrm{b}}$ & $4.84^{\mathrm{b}}$ & 0.10 & $* *$ & NS & NS \\
\hline Leucine & $8.81^{\mathrm{a}}$ & $10.37^{b}$ & $7.64^{\circ}$ & $8.91^{\mathrm{a}}$ & 0.27 & $* *$ & $* *$ & NS \\
\hline Phenylalanine & 3.62 & 3.87 & 3.80 & 3.94 & 0.08 & NS & * & NS \\
\hline Histidine & 3.19 & 3.02 & 3.20 & 3.15 & 0.26 & NS & NS & NS \\
\hline Lysine & $6.03^{a b}$ & $4.60^{\circ}$ & $7.79^{\circ}$ & $6.25^{\mathrm{ab}}$ & 0.40 & $*$ & $* *$ & NS \\
\hline Arginine & 2.14 & 1.95 & 2.29 & 2.21 & 0.07 & $*$ & NS & NS \\
\hline Essential amino acids & 41.31 & 40.29 & 42.83 & 41.28 & 0.77 & NS & NS & NS \\
\hline
\end{tabular}

1) Standard error of means.

2) NS : P >0.05.

$a, b, c$ Mean values in the same row with different superscripts differ significantly $(P<0.05)$.

${ }^{*} \mathrm{P}<0.05,{ }^{* *} \mathrm{P}<0.01$.

て、またCGM メ上りあ SBM 区で高かった（表 4). 反贺罚内で分解された有機物量に対する菌体窒素の合成

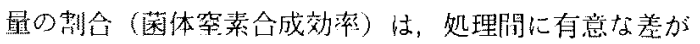

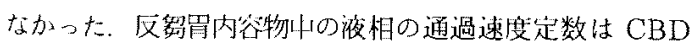
风に比べ BBD 区で高い值在示した $(\mathrm{P}<0.05)$ が, 蛋 白質源の影響はなかった。

十一指腸へ流入した了ミノ酸量ならびに十一指腸内谷 物のアミノ酸組成在表 5 に示した。十一指腸への総アミ ノ酸移行量は BBD 区に比べ CBD 区で $(\mathrm{P}<0.05)$, SBM 区に比べ CGM 区で $(\mathrm{P}<0.01)$ 多かった。十一 指晹八の必須了ミ/酸の流入量は SBM 区に比べ CGM 凶で多かった（P<0.05）ものの，メチオニン・ヒスチ
ジン・リジンの流入量は, デンプン源と蛋白質源の影響 はなかった、アミノ酸組成は CBD 区に比べ BBD 区

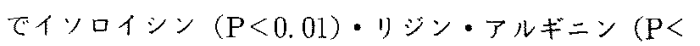
0.05) の割合が高く、 ロイシンの割合は低かった $(\mathrm{P}<$ 0.01)。また SBM 区に比べ CGM 区では，ロイシン $(\mathrm{P}<0.01)$ とフェニルアラニン $(\mathrm{P}<0.05)$ の割合が高 く, 逆にスレオニン $(\mathrm{P}<0.01)$ ・゙リリン $(\mathrm{P}<0.05)$ ・ リジン $(\mathrm{P}<0.01)$ の割合が低かった。

小腸内の必須アミ，酸の消失量は SBM に比べ CGM 区において多く $(\mathrm{P}<0.05)$ ，イソロイシン $(\mathrm{P}<0.05)$

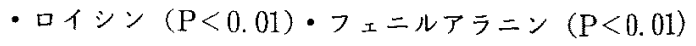
・ヒスチジン $(\mathrm{P}<0.05)$ の消失量が多かった（依6). 
Table 6. Disappearance of amino acids from the small intestine of steers fed diets containing either corn or barley and soybean meal or corn gluten meal.

\begin{tabular}{|c|c|c|c|c|c|c|c|c|}
\hline \multirow[b]{3}{*}{ Amino acids } & \multicolumn{3}{|c|}{ Treatments } & & & & & \\
\hline & \multicolumn{2}{|c|}{ Corn } & \multicolumn{2}{|c|}{ Barle } & \multicolumn{4}{|c|}{ Significance of difference } \\
\hline & $\begin{array}{c}\text { Soybean } \\
\text { meal }\end{array}$ & $\begin{array}{c}\text { Corn gluten } \\
\text { meal }\end{array}$ & $\begin{array}{c}\text { Soybean } \\
\text { meal }\end{array}$ & $\begin{array}{c}\text { Corngluten } \\
\text { meal }\end{array}$ & $\mathrm{SEM}^{1\}}$ & $\begin{array}{l}\text { Starch } \\
\text { effect }\end{array}$ & $\begin{array}{l}\text { Protein } \\
\text { effect }\end{array}$ & $\begin{array}{l}\text { Starch } x \\
\text { protein }\end{array}$ \\
\hline 'lhreonine & 15.0 & 19.9 & 14.1 & 16.7 & 1.8 & $\mathrm{NS}^{2)}$ & NS & NS \\
\hline Valine & 17.6 & 24.8 & 16.9 & 18.3 & 2.2 & NS & NS & NS \\
\hline Methionine & 4.4 & 5.7 & 4.0 & 3.9 & 0.8 & NS & NS & NS \\
\hline Isoleucine & 15.4 & 20.8 & 14.7 & 18.8 & 1.8 & NS & $*$ & NS \\
\hline Leucine & $31.1^{a}$ & $57.1^{b}$ & $23.0^{\mathrm{a}}$ & $34.6^{\mathrm{a}}$ & 2.9 & $* *$ & $* *$ & $* *$ \\
\hline Phenylalanine & $15.8^{a}$ & $25.0^{\mathrm{b}}$ & $15.0^{\circ}$ & $19.2^{\mathrm{ab}}$ & 1.4 & NS & $* *$ & NS \\
\hline Histidine & 8.1 & 12.3 & 6.4 & 10.2 & 1.5 & NS & * & NS \\
\hline Lysine & 24.7 & 24.7 & 30.7 & 28.6 & 3.9 & NS & NS & NS \\
\hline Arginine & 11.1 & 13.5 & 10.4 & 12.3 & 1.3 & NS & NS & NS \\
\hline Essential amino acids & 143.0 & 203.8 & 135.2 & 162.0 & 16.0 & NS & $*$ & NS \\
\hline Total amino acids & $309.9^{a}$ & $468.8^{b}$ & $283.1^{\mathrm{a}}$ & $354.5^{\mathrm{ab}}$ & 30.5 & NS & $* *$ & NS \\
\hline
\end{tabular}

1) Standard error of means.

2) $\mathrm{NS}: \mathrm{P}>0.05$.

${ }^{a}{ }^{b}$ Mean values in the same row with different superscripts differ significantly $(P<0.05)$.

${ }^{*} \mathrm{P}<0.05,{ }^{* *} \mathrm{P}<0.01$.

ロイシンについてはデンプン原の影響も諗められたが， 蛋白質源との交互作用があった $(\mathrm{P}<0.01)$. 小腸から のメチオニンおよびリジンの消失量は，処理間に有意差 がなかった $(\mathrm{P}<0.05)$.

飼料給与前後における㧈装山の遊離アミノ酸莄度を衣 7 に示した，铝料給与前の必須了ミノ酸满度は，処理閒 に差がなかった，飼料給与後では SBM 凶に比へCGM 凶で, 全アミ，酸・必須アミノ酸・メチオニン・ロイシ ン・フェニルアラニン渭度加高々 $(\mathrm{P}<0.01)$, イロ イシン・ロイシン・リジンについてはデンプン源の影響 を認めた，飼料給与前に比へ，飼料給与後では扣等山の 遊離アミノ酸㴗度はCC区を除いて減少する傾向がみ られた。

\section{考 察}

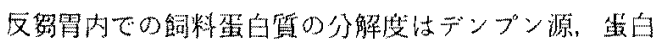
質源双万の影響索受けたが、大豆粕に比ベコーングルテ ンミールの反虽胃内分解度が小さいことはこれまでに

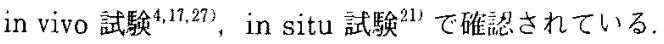
反第胃内におりる飼料蛋白質の分解性に対するデンプン 源の影響については，利用可能エネルギーの増加によっ て微生物の蛋白質分解活性が高まるとの報告があり ${ }^{32}$,
$\mathrm{BBD}$ 区の反罚胃内デンブン・有機物・エネルギー消先 量が CBD 区のそれよりも高かったことから（赫2）。 エネルギー面の影響も否远できない，しかし本試騃の粗 蛋白質給与レベルは飼養檽準 ${ }^{193}$ に兄含っていたとはい え，比較的低く設定しており，全給与粗蛋白質に対する デンブン源としてのトゥモロコシと大麦由来の粗焦白買 制合はそれそれ36\%，46\%に達している，NRC

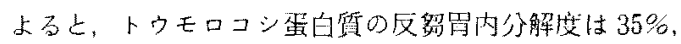
大麦䨞白澌では79\%である。従って全飼料蛋白質の反 留胃内分解度に対する今同のデンプン源の影響は、デン プン燃に含まれる蛋白質の分解度が反咉したものと考え るのが采当であらう。

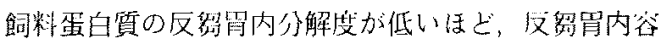

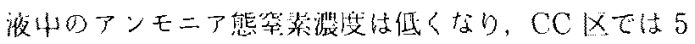
$\mathrm{mg} / \mathrm{d} l$ 义下であった (这4). SATlER and ROFFER ${ }^{24}$

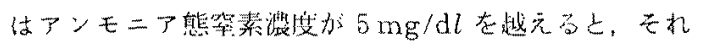

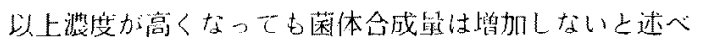
ている.しかし $7 \mathrm{mg} / \mathrm{d} l$ のンモ二ア態紫素濃度索

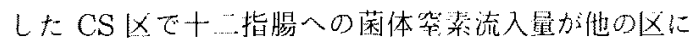
比べて鼠も少なく，同じアンモニア態等装湡度ですった BC 区がそれよりも60\%あ高かった。このことは反思

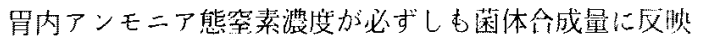


Table 7. Concentration of free amino acids in plasma of steers fed diets containing either corn or barley and soybean meal or corn gluten meal at before feeding and two hours after feeding.

\begin{tabular}{|c|c|c|c|c|c|c|c|c|}
\hline \multirow[b]{3}{*}{ Amino acids } & \multicolumn{4}{|c|}{ Treatments } & & & & \\
\hline & \multicolumn{2}{|c|}{ Corn } & \multicolumn{2}{|c|}{ Barley } & \multicolumn{4}{|c|}{ Significance of difference } \\
\hline & $\begin{array}{c}\text { Soybean } \\
\text { meal }\end{array}$ & $\begin{array}{c}\text { Corngluten } \\
\text { meal }\end{array}$ & $\begin{array}{c}\text { Soybean } \\
\text { meal }\end{array}$ & $\begin{array}{c}\text { Corn gluten } \\
\text { meal }\end{array}$ & SEM $^{\prime \prime}$ & $\begin{array}{l}\text { Starch } \\
\text { effect }\end{array}$ & $\begin{array}{l}\text { Protein } \\
\text { effect }\end{array}$ & $\begin{array}{l}\text { Starch } x \\
\text { protein }\end{array}$ \\
\hline \multicolumn{9}{|l|}{ Before feeding } \\
\hline Threonine & 8.59 & 6.76 & 6.61 & 7.55 & 0.75 & $\mathrm{NS}^{21}$ & NS & NS \\
\hline Valine & 22.83 & 20.62 & 19.85 & 21.89 & 1.22 & NS & NS & NS \\
\hline Methionine & 3.25 & 2.47 & 2.94 & 2.48 & 0.52 & NS & NS & NS \\
\hline Isoleucine & $11.71^{\mathrm{ab}}$ & $9.45^{\mathrm{a}}$ & $11.61^{2 b}$ & $13.51^{\mathrm{b}}$ & 0.69 & * & NS & $*$ \\
\hline Leucine & $14.95^{\mathrm{ab}}$ & $19.12^{\mathrm{a}}$ & $17.79^{\mathrm{ab}}$ & $10.64^{b}$ & 1.15 & $*$ & NS & $* *$ \\
\hline Phenylalanine & 6.16 & 6.14 & 6.16 & 5.00 & 0.28 & NS & NS & NS \\
\hline Histidine & 7.14 & 6.02 & 4.81 & 6.48 & 0.71 & NS & NS & NS \\
\hline Lysine & $10.09^{\mathrm{ab}}$ & $6.65^{c}$ & $11.69^{\mathrm{a}}$ & $8.50^{\mathrm{bc}}$ & 0.34 & $* *$ & $* *$ & NS \\
\hline Arginine & $10.84^{\mathrm{a}}$ & $7.37^{\mathrm{b}}$ & $9.96^{\mathrm{ab}}$ & $9.90^{a b}$ & 0.59 & NS & $*$ & * \\
\hline Essential amino acids & 95.55 & 84.58 & 86.57 & 90.79 & 5.36 & NS & NS & NS \\
\hline Total amino acids & 227.74 & 195.40 & 215.18 & 222.20 & 11.66 & NS & NS & NS \\
\hline \multicolumn{9}{|c|}{ Two hours after feeding } \\
\hline Threonine & 5.78 & 6.97 & 5.31 & 6.57 & 0.35 & NS & NS & NS \\
\hline Valine & $15.79^{\mathrm{a}}$ & $20.52^{b}$ & $16.86^{\mathrm{ab}}$ & $15.85^{\mathrm{a}}$ & 0.84 & NS & NS & * \\
\hline Methionine & $1.96^{\mathrm{a}}$ & $2.91^{\mathrm{b}}$ & $2.16^{\mathrm{ab}}$ & $2.27^{\mathrm{ab}}$ & 0.11 & NS & $* *$ & $* *$ \\
\hline Isoleucine & $7.51^{\mathrm{a}}$ & $9.13^{\mathrm{ab}}$ & $9.77^{b}$ & $8.46^{\mathrm{ab}}$ & 0.31 & * & NS & $* *$ \\
\hline Leucine & $9.63^{a b}$ & $18.44^{c}$ & $8.23^{\mathrm{a}}$ & $13.06^{b}$ & 0.68 & $* *$ & $* *$ & $*$ \\
\hline Phenylalanine & $4.16^{\mathrm{a}}$ & $6.36^{b}$ & $4.21^{\mathrm{a}}$ & $5.02^{\mathrm{ab}}$ & 0.27 & NS & $* *$ & $*$ \\
\hline Histidine & 4.59 & 7.49 & 3.95 & 6.36 & 0.76 & NS & NS & NS \\
\hline Lysine & $6.44^{\mathrm{ab}}$ & $6.22^{\mathrm{a}}$ & $8.22^{b}$ & $6.51^{a b}$ & 0.41 & $*$ & NS & NS \\
\hline Arginine & 6.68 & 7.71 & 7.60 & 6.87 & 0.31 & NS & NS & NS \\
\hline Essential amino acids & $62.54^{\mathrm{a}}$ & $85.75^{b}$ & $66.31^{a b}$ & $70.07^{\mathrm{ab}}$ & 3.13 & NS & $* *$ & $*$ \\
\hline Total amino acids & $153.56^{\AA}$ & $199.01^{\mathrm{b}}$ & $166.92^{\mathrm{ab}}$ & $177.42^{\mathrm{ab}}$ & 5.37 & NS & $* *$ & * \\
\hline
\end{tabular}

するむのではないことを意味している。

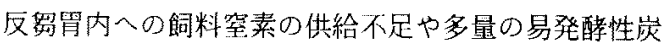
水化物の存在によって，娷液腺あるいは胃壁を通じて反 罗罥内へ流入する空菜量が增加する15,237、コーングルテ ンミールを給与したCC 区と BC 区で摄取量を上问る 窂素量か十十“指腸に流入したのは、リサイクル窒素から の菌体聜菜合成量が增加したためであり，その結果十二 指腸菌体移行量に対する絰素源の影響がなかったと判断 される.

一方，十一指腸に流入した菌体量はデンプン源の影響 を受け，BBD的で高かったのは反臅内でのデンプン，
有機物消失量と関連している，SPICER ら ${ }^{27)}$ は去勢牛に 大麦, トゥモロコシあるいはりルガムを給与すると，デ ンプンの反㫚胃内分解度の高い大麦給与で反忽胃内デン プン消头量が高く，十二指腸流人菌体量も多かったと報 告しており，同様な結果は，泌乳牛を用いた試験 ${ }^{18)}$ 本得られている.

菌体合成量は菌体の利用可能エネルギー量によって左

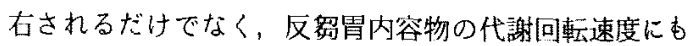
影響される. TELLER ら ${ }^{31)}$ は泌乳牛において液相の通過 速度之菌体窒素合成効率との間に正の相関があることを 示し，菌体蛋白質の十二指腸への流入速度に影響怘及注 
す主たる要因は液相の通過速度であると述べている，本 試験での液相の反侣胃通過速度は，デンプン源の影響を 受けて BBD 区で大きい值を示した，HOOVER ら ${ }^{12)}$ は， 通過速度が有機物消化量ならびに菌体合成量に及ぼす影 響は $\mathrm{pH}$ によって大きく異なり，pH 6.5 では通過速度 の上暴に伴い有機物纷解量加増加し菌体合成量も堌加す ることを連続培養試験により示した，今回の反㫚胃内容 液の日平均 $\mathrm{pH}$ は処理間に差がなく6.5 6.6の範囲で あった．BBD 区で菌体空素合成量が多かったのは液相 の反筷罢通過速度が大きかったこと要因の1つであっ たと考えられる。

本試験での十二指腸へ流入した䇪素量に対する小晹内 消失量の割合は，流入菌体窒素之飼料由来窒素の比率や デンプン源，蛋白質源に関係なく，62〜66\%の範囲に あり，他の報告值 ${ }^{38)}$ に近かった。 十二指腸に流入した 窒素化合物中の菌体窒素の割合が変化しても，小腸内で の見办计の窒素消化率に差がないこよはこれまでにも報 告されている ${ }^{18,27)}$ ．そこで全測定値 $(n=16)$ をプール して小腸における流入窒素量上消失窒素量よの関倸につ いて一次回㷌式を求めたところ以下の式を得た。

$$
\mathrm{Y}=0.77 \mathrm{X}-0.21 \quad \mathrm{R}^{2}=0.976
$$

$\mathrm{Y}$ は代謝体重あたりの小腸内消失窒素量 $\left(\mathrm{g} / \mathrm{kg}^{0.75} /\right.$ 日)，X は代謝体重あたりの䇪素流入量 $\left(\mathrm{g} / \mathrm{kg}^{0.75} /\right.$ 日) を示している. 式の傾きから，本試験の小腸における窒 素の真の消化率は 77\% であり，ZINN and OWENS ${ }^{38)}$ の 73\%に近い值であった，また，式の切片から回腸末端

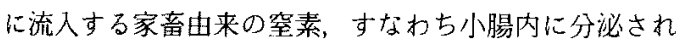
ても消失しない内因性效素量は，代謝体重あたり 0.21 $\mathrm{g} /$ 日であり, 羊での值 ${ }^{29)}(0.26 \mathrm{~g} /$ 日) 亿近似していた.

回腸末端への流入堂素量は処理による差がなかったに あかかわらず，䔬中等菜排泄量はデンプン源の影響を受 けた，大腸から吸収される主な䈍素化合物はアンモニア 態窒菜である ${ }^{11}$ が，デンプンの大腸内可消化量が増加 する之，内因性空素や内容物中の窒素化合物加らの菌体 窒素合成量加增加し，そのため粪中窒素排泄量が高まる こと加指摘されている221. 前報 ${ }^{30)}$ で示したように, CBD 区では BBD 区に比べより多くのデンプンが大腸 内で消化されていることから，CBD 区で大晹内菌体窒 菜合成量加增加したと推察される。

十二指腸への流入了ミ，酸に関して，大豆粕の代わり にコーングルテンミールを給与する上，トゥモロコシ蛋 白質中のロイシン含量が高いためにロイシン流入量が增 えることが指摘されている、16,17). また去勢牛に大麦， トウモロコシあるいはソルガムを給与した場合に，トウ モロコシ給与で第四胃への菌体窒菜流入量隇少とロイシ
ン流入量の增加が観察されている27. 本試験でもこのこ とが確認されたか，CC 区でのロイシン流入鼠は他の区 に比ベて著しく高加った，デンプン源と蛋片質源との闑 の交互作用が有意であったことから，トゥモロコシとコ ーングルテンミールの組合せでは，相乗的にロイシン流 入量加堌加するの加ししれない，ロイシンとは逆に，リ ジンは一般にトゥモロコシ蛋白質中の含有率加低い，事 奏, 十二指腸内容物中のアミ/酸組成をみる限り，トゥ モロコシ給与あるいはコーングルテンミール給与によっ て隇少している。しかし CC 区の上うに，十二指晹内 容物中のリシン含量がかなり少なくても，非アンモニア 態呿素流入量が多くなると，リジン流入量は処理間差が 生じない。

総アミノ酸, 必須アミノ酸, メチオニンおよびリジン の十二指腸流入量に対する小腸内消失量の割合は処理の 影響を受けなかったので，前述の窒素の場合之同様に，

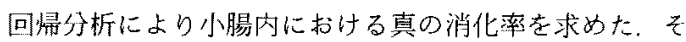
の結果，総了ミノ酸方よび必須了ミ,酸の真の消化率は それぞれ92、93\% であり，それに比ベメチオニンおよ びリジンの消化率は 103，105\% と高い值となった，他 のアミノ酸に比ベメチオニンの消化率は高いことは既に

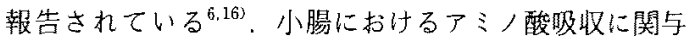
する能動輸送系は，一般に4 種類認好らてたり，同じ 担体で輸送されるアミ，酸間に拮抗作用がある10 WEBB and BerGMAN ${ }^{35}$ は, 酸の吸収を阻害するむのの, 他のアミノ酸に上る吸收阻 害を受けにくいと述へている。一方，リジンの吸収は口

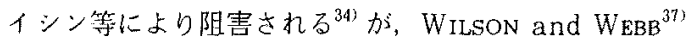
は，消化管管㓐内加ら小腸細胞へのリジン輸送経路は管 腔内のリジン濃度によって大きく变化し，濃度が低い場 合，晹内細胞へのリジンとメオニンの吸収速度に差が なかったことを错察している。

血嶈中の遊離アミノ酸濃度は，CC 区を除いて飼料給 与後 CS, BS, BC 区でそれぞれ給与前の $65 ， 77 ， 77 \%$ まで低下した，BERGEN ${ }^{23}$ は，飼料搷取值後では血脽中 のアミノ酸プールからの組織内へのアミノ酸取り込み速 度が小腸加らのア，酸吸収速度を上回るため，血㢡中 の遊離アミノ酸瀑度が低下し，エネルギー投与に伴うこ の低下は組織への取込み老示するのであると述べている。 BERGEN ${ }^{21}$ の説を支持するならば，CC区では小腸から のアミ/酸吸収皇は多かったものの，をれに見合うはど 血趢中のアミノ酸プールから組織細胞内への取込みか增 加しなかったと見なせる。

小腸からの窒菜扔よび必須アミ/酸消失量はコーング ルテンミール給与区，特にCC区で增加したものの， 


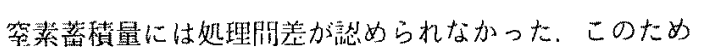
小腸内消失器素量に対する䈉菜蓄槕は $\mathrm{CC}$ 区でもっと 低い值を示した。 TITGEMEYER ら ${ }^{331}$ は，去勢牛にコ ーンサイレージ，トウモロコシ执よ゙尿素を給与した結 果, リジンが第一制限アミノ酸になったと述べている. またトウモロコシとコーングルテンミールを給与して

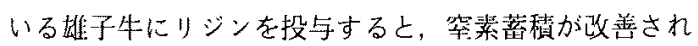
たという綪果いすある。今四の CC メでは，十一指腸 へ流入した蛋白貿のリジン含是あるいは的等中の遊離り

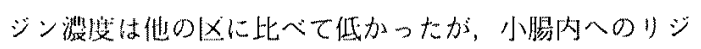

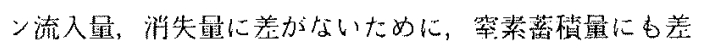
が生じなかった上考えられる。しかし本試験の場合，可 消化エネルギー揁取量が全爻を通して 61〜64 MJ/日と 比較的低いレベルで一走していたこと，供試牛の体重が 大きく(試験期閐平均: $260 \mathrm{~kg}$ )，蛋白質，アミ／酸要 求量が比較的低加ったことも，小腸内アミ，䣮消失量の 迲いが空素蓄䅡に反映しなかった原区として考虑されな ければならない。

本試鏏全体を通して，CC区では他の凶に比べ等菜の 利州性が著しく異なっっいたこのCC区での穼素の 流㧈については他の区との比較においてお扰よそ次のこ とが恶えよう。すなわち，摂取窒素量は他の区と同じで

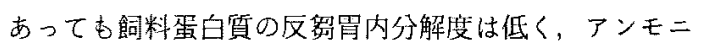
了濃度手低いため内因性空素量加增加し，それを利用し ての菌体案素合成が多い。その結果，十二指腸に流入す る菌体案素プラス飼料由来究素量は増加するが，小腸内 での案素消化率には処理による差がないので吸收茅素量 6多くなる、吸收された聜素化会物のうち過剩な空素は

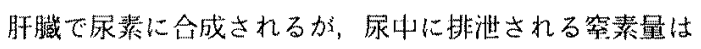

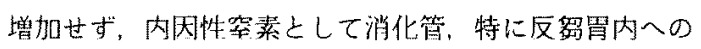
流入最が县える.

以上のことをまとめると，大麦あるいはトウモロコシ と大豆粕あるいはコーングルテンミールを組合せて去勢 4に給与した場合，反焣胃内藏体合成量は，デンプンお よび有機物の反留罢内分解度の高い大麦給与で増加する が，飼料蛋白質の反䀜置内分解舆の低いコーングルテン ミールの維与で内因性管娇の反留胃入の移行量が增加す

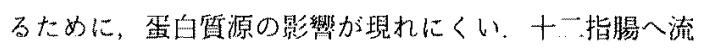

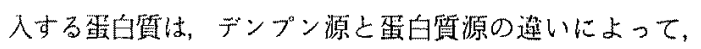
飼料由来の蛋白質と菌体蛋白質の割合やアミノ酸流入量 とその組成が鼠なるが，小腸内に打ける学紊消化率には 処理による差がない，その結果，小腸への窒素流入量が

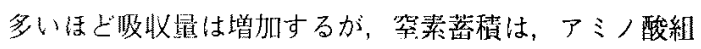
成，家音の要求レベルあるいはエネルギー掑取レベルに

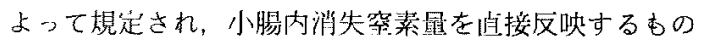

ではない。このような状沉下でトウモロコシとコーング

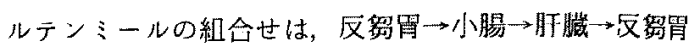

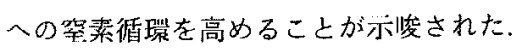

\section{文献}

1) Agricultural Research Council Working Party, The nutrient requirements of ruminant livestock, supplement no. 1. 1-36. Commonwealth Agricultural Bureaux. London. 1984.

2) Bergen, W.G., Free amino acids in blood of ruminants-physiological and nutritional regulation. J. Anim. Sci., 49: 1577-1589. 1979.

3) Broderick, G.A., R.J. WALlace and E.R. Orskov, Control of rate and extent of protein degradation. in Physiological aspects of digestion and metabolism in ruminants. (TSUDA, T., Y. SASAKI and R. Kawashima eds.) 541-592. Academic Press. San Diego. 1991.

4) Cecava, M.J., N.R. Merchen, L.L. Berger and D.R. NELSON, Effect of energy level and feeding frequency on siti of digestion and postruminal nutrient flows in steers. J. Dairy Sci., 73 : 2470-2479. 1990.

5) Cecava, M.J., N.R. Merchen, L.L. Berger and G.C. FAHEY, JR., Effects of dietary energy level and protein source on site of digestion and duodenal nitrogen and amino acid flows in steers. J. Anim. Sci., 66 : 961-974. 1988.

6) Christiansen, M.L. and K.F. WebB, Jr, Intestinal acid flow, dry matter, starch and protein digestibility and amino acids absorption in beef cattle fed a high-concentrate diet with defuorinated rock phosphate, limestone or magnesium oxide. J. Anim. Sci., 68 : 2105-2118. 1990.

7) Cunico, R.L. and T. Schlabach, Comparison of ninhydrin and o-phthalaldehyde post-colum detection techniques for highperformance liquid chromatography of free amino acids. J. Chromatogr., 266 : 461-470. 1983.

8) Dong, M.W. and J.R. Gant, High-speed liquid chromatographic analysis of amino acids by post-colum sodium hypochlorideo-phthalaldehyde reaction. J. Chromatogr., 327: 17-25. 1985.

9) Grovum, W.L. and V.J. Williams, Rate of passage of digesta in sheep. Brit. J. Nutr., 


\section{去㙯牛の消化管部住别究菜消化}

$30: 231-240.1973$.

10）荻平 博，アミ／酸の吸收とアミ，酸㡏造に其朝 した代謝，新生理兴大系 18 ・消化と吸收の生理 学（军 猛・滕田道也 編）186-193. 医觉書 院. 東宗。 1988.

11) Hoover, W.H., Digestion and absorption in the hindgut of ruminants. J. Anim. Sci., 46: 1789-1798.

12) Hoover, W.H., C.R. Kincaid, G.A. VARGA, W.V. ThayNe and L.L. JUNKINS, JR, Effects of solids and liquid flows on fermentation in continuous cultures. VI. $\mathrm{pH}$ and dilution rate. J. Anim. Sci., 58: 692-699. 1984.

13) Hoover, W.H. and S.R. Stokes, Balancing carbohydrates and proteins for optimum rumen microbial yield. J. Dairy Sci., 74 : 3630-3644. 1991.

14）入来常德・㔯方敬子・阿部又信，低蛋白犋椇取条 件下の4５力月龄子牛におけ方第一筒内北分解 性蛋白質口必要性。 日畜全㫰，63：414-419, 1992.

15) Kennedy, P.M. and L.P. Milligan, Transfer of urea from the blood to the rumen of sheep. Brit. J. Nutr., 40 : 149-154. 1978.

16) Koeln, L.L. and J.A. Paterson, Nitrogen balance and amino acid disappearance from the small intestine in calves fed soybean meal-, toasted soybean meal- or corn gulten meal supplemented diets. J. Anim. Sci., 63: 1258-1266. 1986.

17) KLUSMEyer, T.H., R.D. MCCARThy, JR and J.H. CLARK, Effects of source and amount of protein on ruminal fermentation and passage of nutrients to small intestine of lactating cows. J. Dairy Sci., 73 : 35263537. 1990.

18) MCCARThy, JR, R.D., T.H. Klusmeyer, J.L. Vicini, J.H. Clark and D.R. Nelson, Effects of source of protein and carbohydrate on ruminal fermentation and passage of nutrients to small intestine of lactating cows. J. Dairy Sci., 72: 2002-2016. 1989.

19) National Research Council, Nutrient requirements of beef catile. National Academy Press. Washington, D.C. 1984.

20) National Research Council, Ruminant nitrogen usage. National Academy Press. Washington, D.C. 1985.

21) Okubo, M., M. Hanada, J. Sekine, Y. MiURA and Y. AsAHIDA, The rumen degradability of protein for various feedstuffs. J. Fac. Agr. Hokkaido Univ., 63: 49-53. 1986.
22) ORskov, E.R., Starch digestion and utilization in ruminants. J. Anim. Sci., 63: 1624-1633. 1986.

23) ORskov, E.R. and M. RYLE, Energy nutrition in ruminants. 43-51. Elsevier Applied Science. London and New York. 1990.

24) SAtter, L.D. and R.E. Roffer, Influence of nitrogen and carbohydrate inputs on rumen fermentation. in Recent develop ments in ruminant nutrition. (HARESIGN, W. and D.J.A., CoLE, eds.) 115-139. But. terworths. London. 1981.

25) Smith, R.H., Substances in the calf alimentary tract interfering in the determination of polyethylene glycol. Nature. London, 182 : 260-261. 1958.

26) Smith, R.H. and A.B. McAllan, Some factors influencing the chemical composition of mixed rumen bacteria. Brit. J. Nutr., 31 : 27-34. 1974.

27) Spicer, L.A., C.B. Theurer, J. Sowe and T.H. Noon, Ruminal and post-ruminal utilization of nitrogen and starch from sorghum grain-, corn- and barley-based diets by beef steers. J. Anim. Sci., 62:521530. 1986

28) Steel, R.G.D. and J.H. Torrie, Principles and procedures of statistics. 2nd ed. McGraw-Hill Publishing Company. New York. 1980.

29) Storm, E. and E.R. Orskov, Biological value and digestibility of rumen microbial protein in lamb small intestine. Proc. Nutr. Soc., $41: 78$ A. 1982.

30) Taniguchi, K., M. Hanada, T. Obitsu and Y. Yamatani, Combinations of different sources of starch and protein: effect on site and extent of carbohydrate digestion in steers. Anim. Sci. and Technol. (Jpn.) 62 : 699-710. 1991.

31) Tfller, F., M. Vanbelle, M. Foulon, G. Collignon and B. Matatu, Nitrogen metabolism in rumen and whole digestive tract of lactating dairy cows fed grass silage. J. Dairy Sci., 75 : 1296-1304. 1992.

32) Titgemeyer, E.C., N.R. Merchen and L.L. Berger, Evaluation of soybean meal, corn gluten meal, blood meal and fish meal as sources of nitrogen and amino acids disappearing from the small intestine of steers. J. Anim. Sci., 67 : 262-275. 1989.

33) Titgemeyer, E.C., N.R. Merchen, L.L. Berger and L.E. Deerz. Estimation of 


\section{花田・小匮・谷口}

lysine and methionine requirements of growing steers fed corn silage-based or corn-based diets. J. Dairy Sci., 71:421434. 1988 .

34) WEBB, JR, K.E., Intestinal absorption of protein hydrolysis products: a review. J. Anim. Sci., 68: 3011-3022. 1990.

35) WebB, JR, K.E. and E.N. Bergman, Amino acid and peptide absorption and transport across the intestine. in Physiological aspects of digestion and metabolism in ruminants. (TsudA, T., Y. SASAKT and R. Kawashima eds.) 111-128. Academic Press. San Diego. 1991.

36) Wilson, P.N. and P.J. Strachan, The contribution of undegraded protein to the protein requirements of dairy cows. in Recent developments in ruminant nutrition. (HAREsign, W. and D.J.A., Cole, eds.) 228-247. Butterworths. London. 1981.

37) WrLtsoN, J.W. and K.E. WEBB, JR, Lysine and methionine transport by bovine jejunal and ileal brush border membrane vesicles. J. Anim. Sci., 68:504-514. 1990.

38) ZINN, R.A. and F.N. OWens, Site of protein digestion in steers: predictability. J. Anim. Sci., 56 : 707-716. 1983.

39) ZnNN, R.A. and F.N. Owens, A rapid procedure for purine measurement and its use for estimating net ruminal protein synthesis. Can. J. Anim. Sci, 66 : 157-166. 1986. 


\title{
The Effects of Different Starch Sources and Protein on Site and the Extent of Nitrogen Digestion and Utilization in Steers
}

\author{
Masaaki Hanada, Taketo OBItsu ${ }^{*}$ and Kohzo Taniguchi ${ }^{*}$ \\ Konsen Agricultural Experimental Station, \\ Nakashibetsu-cho Hokkaido 086-11 \\ *Faculty of Applied Biological Science, Hiroshima \\ University, Higashihiroshima-shi 724
}

Four steers fitted with ruminal, duodenal and ileal cannulas were used in a $4 \times 4$ Latin square design, in order to investigate the effects of four combinations of starch and protein sources on nitrogen utilization in the digestive tracts and nitrogen balance. Starch sources were corn and barley; protein sources were soybean meal (SBM) and corngluten meal (CGM). Treatments were also arranged as $2 \times 2$ fractional. Steers ( $227 \mathrm{~kg}$ body weight) were fed isonitrogenous (11\% CP) diets of $50 \%$ hay and $50 \%$ concentrate, and provided with sufficient digestible energy to support a growth rate of $0.7 \mathrm{~kg} / \mathrm{d}$. Microbial nitrogen flow to the duodenum was greater for barley than corn ( $P$ $<0.05$ ), but was not affected by protein sources. Total- and dietary-nitrogen flows to the duodenum, however, were greater for corn than barley and greater for CGM than SBM $(\mathrm{P}<0.01)$. Nitrogen disappearance from the small intestine increased linearly with increased nitrogen flow to the duodenum; thereby, small intestinal digestibility of nitrogen was not affected by starch and protein sources or by the different ratios of microbial and dietary nitrogens. A regression analysis between duodenal flow and small intestinal disappearance of nitrogen showed $77 \%$ true digestibility in the small intestine. Duodenal fow and intestinal disappearance of total essential amino acids did not differ between starch sources, but increased for CGM over SBM $(P<0.05)$. No difference in lysine disappearance in the small intestine may result in a similar nitrogen retention among treatments despite different lysine content in duodenal digesta. A combination of corn and CGM seems to increase the amount of nitrogen recycled through the rumen, the small intestine and the liver.

Anim. Sci. Technol. (Jpn.) 64 (3) : 275-287, 1993

Key words : protein degradation, starch, amino acids, intestinal digestion, steer 